\title{
DIPLOMACY IN THE PERSPECTIVE OF BOUNDARIES
}

- Buddhi Narayan Shrestha

\begin{abstract}
Diplomacy is an instrument for negotiation to find mutually acceptable solutions to a common challenge in a non-confrontational and polite manner. In this perspective, border diplomacy refers to the diplomatic approaches to demarcate, manage and resolve the border disputes in a peaceful manner. For Nepal, border diplomacy for demarcation and management should be based on the dynamic equilibrium of both the neighbours, China and India. This paper revisits the crux of diplomacy and border diplomacy for the peaceful settlement of disputes in a peaceful way. The research emphasizes on border demarcation diplomacy, focussing on Nepal-India and Nepal-China borders. The study explains about the border dispute between Nepal and India in the region of Lipulek, Limpiyadhura and Kalapani. Further, the paper suggests border management diplomacy for Nepal-China and Nepal-India, focusing on the Kalapani issue, and alerts about the possible circumstances during the negotiations and recommends Nepal's potential strategies for border management in the future.
\end{abstract}

Keywords: Nepal-India Borderlands, Border Management Diplomacy, Border Demarcation Diplomacy, Broader Strategy

\section{Background}

The word "diplomacy" comes from the Latin word "diploma" which refers to an official document, which in turn is derived from the Greek word $\delta i ́ \pi \lambda \omega \mu \alpha$ (diploma), which meant document folded over (Constantinou, 1996, p. 77). But in modern international relations, diplomacy is the process of conducting negotiations between representatives of groups or states. Comprehensively, diplomacy as a tool of foreign policy refers to the conduct of international relations through professional diplomats and experts concerning the issues of peacekeeping, trade, war, economics and culture, and ushering international treaties, agreements, alliances and other manifestations of foreign policy (Melissen, 2005).

He is a prominent border expert from Nepal. He worked 27 years in the land survey department (five years as Director General) and nearly four years as a mapping consultant in the ADB and World Bank funding projects in Nepal. He is the founder President of Nepal Institution of Chartered Surveyors. 
Colloquially, diplomacy is the employment of tactics to gain strategic advantage or to find mutually acceptable resolutions to a mutual challenge. It is a set of tools non-confrontational and non-coercive tool of foreign policy, as well as the process and machinery of negotiation. It is an important instrument of formulating and executing foreign policy. It is the demeanour or management of international relations by the application of intelligence and tactfulness to conduct the official relations amongst governments and independent states. It is mostly concerned with foreign policy and with the process of making and implementing policies (Kertesz \& Fitzsimons, 1959, p. 266).

Geographical proximity definitely increases interactions among countries. could invite risk situations. In basic conceptualisation, borders are an opportunity for interaction driven by proximity, Border regulates the level of relationship amongst border-sharing states (Ullah \& Kumpoh, 2018).

All the shared borders are characterised by different kinds and forms of separators. After the nation-states came into being, these separators began to yield a range of relationships, and thus became shared elements (Ullah \& Kumpoh, 2018). The states sharing borders are even more dependent on each other. But, the dependency through borders becomes overshadowed by the advent of security issues in the global discourse.

Borders, in the international arena, are a contested area where debates have received renewed attention. Traditional diplomacy and foreign policy were engaged in the aspects of war and peace, and now, the border agenda has undergone enormous expansion in the last few decades, and border controls and security perceptions have changed significantly (Ullah \& Kumpoh, 2018, p. 3). Also, boundary demarcation is a complex phenomenon as it is based on both domestic and international legislation. The boundary agreement between states may be an international legal document, but its making and ratification of the boundary are an exclusively internal political process. Likewise, during the delimitation phase, negotiations take place before the signing of an agreement. Those negotiations may be complex and tense, which may lead to serious disagreements among the parties (Nordquist, 2010).

Borders define a state's territoriality and provide a way for state sovereignty, but the relational nature of borders infringes upon the same sovereignty as well. Thus, a borderline can be a probable mirror of inner disputes as well as the origin of an interstate clash in itself. As boundaries are a relational, complex and potential source of conflict, preventive diplomatic measures through negotiations can de-escalate boundary conflicts in the world. This preventive diplomacy for de-escalation takes place under the framework of 
international law. In the contemporary world, the use of force against any state in a conflict is not considered appropriate. So, the settlement of disputes pacifically is the underlying principle to build confidence in the international community to international laws' commitment towards world peace (HeinrichBöll-Stiftung, 2004). International law exercises its elemental effect through the application of international arbitration or tribunals, which generates the merit of depoliticising a dispute by referring it to technical experts. In this regard, the International Court of Justice (ICJ) has been an advantageous and effective arbitrary mechanism for disputes in present times (Chetail, 2003).

The most fundamental way of peacefully settling territorial disputes is under international law. International law regulates the relations between states, and any disputes between states should be resolved through pacific means and in accordance with the principles of international law. The preservation of international peace and security is the major purpose of international law and the basic objective behind the creation of the League of Nations in 1919 and the United Nations in 1945 (Hamza \& Todorovic, 2017).

In line with this, Article 33 of the UN Charter states that "the parties to any dispute, the continuance of which is likely to endanger the maintenance of international peace and security, shall, first of all, seek a solution by negotiation, enquiry, mediation, conciliation, arbitration, judicial settlement, resort to regional agencies or arrangements, or other peaceful means of their own choice." (The United Nations, 2017). The principle of pacific settlement of disputes provides various ways of settling disputes among states, for which international law is the substantive criteria for solving a dispute.

On the contrary, in the case of actions concerning threats to peace, breaches of peace and acts of aggression, which are to be determined by the United Nations Security Council (UNSC), it may call upon the members to apply measures such as complete or partial interruption of economic relations as well as rail, sea, air, postal, telegraphic, radio and other means of communication, and the severance of diplomatic relations. If these actions seemed to be inadequate, the UNSC shall take actions which include demonstrations, blockades and other operations by air, sea or land forces of the members of the United Nations (The United Nations, 2017). However, of the many measures taken for the settlement of disputes, the main aim is to maintain international peace and security. 
Therefore, for inter-state boundary disputes, the UN Charter and other regional and international documents stipulate, directly or indirectly, the settlement of disputes through peaceful means. Nevertheless, situations do arise where the boundary-related issues could escalate into a serious crisis before they can be settled through pacific means. These irreconcilable circumstances also involve military exchanges between the disputing sides. Thus, boundaries, whether regulated or not, and boundary relations have always been and will remain a potential source of conflict in the world.

Diplomacy from the perspective of boundaries is the art and practice of conducting international boundary negotiations and agreements between states (Martínez, 2018). It calls for the intercession of professional diplomats and experts versed in the subject of peace-making to reach a common understanding. Moreover, border diplomacy is the use of tact to gain strategic advantage or to find commonly satisfactory answers to a common problem on the foundation of historically authentic documents and materials, which could be convenient for both sides in a congenial environment. Similarly, border diplomacy is an enterprise which demands a tireless supply of talented individuals with facts, figures and past incidents to convey and convince neighbouring boundary and surveying experts, in one of the alternative ways (Read, 1990).

Therefore, the diplomatic practice or steps by the states to resolve border disputes in a peaceful manner through demarcation and management is called border diplomacy. It not only deals with territorial dispute settlement but in a broader sense also deals with immigration, refugees and other related matters. Thus, border diplomacy highlights the management of border disputes that are deeply affected by the contradictory interests of various layers of government and 'twilight' entities that project statecraft at the periphery (Henrikson, 2000). It deals with the settlement of territorial disputes and maritime delimitation issues and revolves around their characteristics. Consequently, for international peace and security, border diplomacy deals with the settlement of border disputes, encouraging the practitioners of foreign policy and diplomacy to exercise international law effectively and strategically, and concurrently guide political leaders and the public to deepen their understanding of the practicality and limitations of international law.

In the world today, there are several border disputes which are a threat to international peace and security as well as other security threats such as proliferation of nuclear weapons. Sometimes, leaders cross the borders or meet at the disputed areas to negotiate and resolve the disputes or for other negotiations. In 1999, Indian Prime Minister Atal Bihari Bajpayee and a high- 
profile delegation went to Pakistan across the Wagha border and were received by Pakistani Prime Minister Nawaz Sharif (International Crisis Group, 2012).

\section{Two-minute Diplomacy on the Border}

On June 30, 2019, U.S. President Donald Trump and North Korean leader Kim Jong Un met at the highly fortified DMZ between North and South Korea and agreed to restart negotiations on the long-elusive nuclear agreement (US Embassy and Consulate in the Republic of Korea, 2019). DMZ is considered one of the world's most dangerous areas but the Joint Security Area (JSA) itself is a meeting point between the two states for negotiations.

President Donald Trump used his Twitter account to send an invitation to the North Korean leader to meet him at the DMZ, to which the latter responded positively. This two minutes of diplomacy on one of the most significant borders in the world carried risks and rewards for both men. It brought President Trump's goal of denuclearisation and elevated the North Korean leader's stature in his country, aiding to legitimise his rule (Sigal, 2020).

This was symbolic diplomacy and more than just a handshake, which later turned into a bilateral meeting at the Freedom House, where the leaders agreed to send their negotiators back to the table to seek a long-elusive agreement on North Korea's denuclearisation. Though this meeting of the two leaders at the border and private talks in South Korea has not had real outcomes for denuclearization, the rivalry between the two states in the future could turn into successful mutual relations due to the border diplomacy facilitated by South Korean President Moon Jae-In (Kim \& Snyder, 2019).

\section{Border Disputes Mediation Diplomacy}

Threats to international security are instigated not only by inter-state relations but also by instability and conflicts within states that threaten to spill over into the international arena. In international relations and diplomacy, many techniques and methods have been used to successfully manage and resolve conflicts, such as negotiations, mediation, conciliation, judicial settlements, enquiry arbitration and other peaceful means. Thus, mediation is one of the measures of settling disputes in which a third party is utilised to reduce the differences or to seek a solution (Sargsyan, 2003).

Indian and Chinese soldiers have been engaged in an aggressive standoff in the Laddakh region since May 5, 2020, to which, U.S. President Donald Trump has sought to mediate in the border dispute. President Trump on May 27 offered to "mediate or arbitrate" in the border dispute, citing it is "a big conflict between India and China". As part of the border dispute mediation 
diplomacy, President Trump mentioned that the USA was "ready, willing and able" to ease the tensions amid the continuing standoff between the armies of the two Asian giants (Kazmin, 2020). China, however, rejected the mediation offer, saying it did not want 'intervention' from a third party to resolve the military standoff. India, too, diplomatically turned down the offer, stating that India was engaged with China to peacefully resolve the border dispute (Laskar \& Patranobis, 2020).

Previously also, President Trump had offered to mediate to ease tensions between India and Pakistan on the Kashmir issue. The border dispute mediation diplomacy was proposed to Pakistani Prime Minister Imran Khan on July 22, 2019 by President Trump, citing that Indian Prime Minister Narendra Modi had sought his mediation, which was eventually denied by India. Also at the 45th G-7 Summit in France, President Trump extended the mediation proposal, but Indian Prime Minister Modi politely but firmly rejected it (Roche, 2020). These incidents demonstrate America and President Trump's willingness to see border diplomacy materialise through mediation, although it has not been successful.

In this way, mediation has been a process of peaceful settlement of disputes. The process of mediation in border diplomacy is especially an important aspect in securing international peace and security. Thus, border dispute mediation diplomacy is a major instrument in demarcating, regulating and monitoring the boundaries so that the conflict doesn't escalate further between the states.

\section{Border Demarcation Diplomacy}

Border diplomacy constitutes aspects of international relations. It takes help of international low and diplomacy to deal with the issues of border management migration, refugees, immigration, maritime borders, mobility of people through the borders, peaceful settlement of disputes and others. Boundary as a political entity governs people's lives within it and significantly affects the lives of the people living near it. Borders, or the demarcation lines between states, are also associated with natural formations and come in the form of rivers, mountain ranges, peaks, narrow passes, lakes and others (Anne-Laure \& Szary, 2015).

In contrast to the concrete natural or man-made boundaries that separate the peoples between two states, some areas on the globe are characterised by homogenous topography along with identical human behaviour, food habits, similar attire and languages on both the frontiers (Bruns, 2017). For example, the porous border between Nepal and India can be taken as an example. There is no conspicuous demarcation of the border between India and southern part of Nepal with a homogenous and similar culture, religion, language and traditions. 
Boundary demarcation of the states comprises actual lying down of the boundary pillars or other similar physical structures based on the framework of the terms of reference in the negotiations. It includes allocation, treaty or agreement on delimitation of the boundary line, and the ongoing frontier administration for boundary maintenance. It also refers to the alignment of stones, concrete pillars of various kinds and also the cleared roads are to be inscribed (McMahon, 1935).

A political framework of boundary allocation, demarcation, delimitation and documentations are practised, whereas a professional framework of boundary maintenance and boundary administration is used (Srebro \& Shoshany, 2013). As boundary demarcation is an aspect of diplomatic negotiations, diplomatic norms are taken into consideration between the neighbouring states. The norms are as follows:

1. The border between two states shall be demarcated through a joint working basis with equal footing. As the border is common for both the states, strip maps and Geographic Information System (GIS) data regarding border issues shall be prepared and established jointly.

2. All the problems related to boundary demarcation shall be resolved on the principle of friendship, brotherliness, mutual respect, understanding and reciprocity.

3. Old maps, documents, coordinates and reference materials shall be used to demarcate the borders.

4. A Joint Technical Level Committee and High-Level Joint Commission with equal participation shall be formed to settle the differences if present in some segments of the borderline.

5. For the amicable settlement of the problems, Track-II diplomacy shall be adopted to find out the modality, ways and means to make study and research. A solution paper should be formed based on facts, figures and past incidents by the diplomats. For this purpose, both parties should be in contact with the counterparts of the neighbouring states.

6. A political level discussion should be conducted on the content of the solution paper and should be passed by a majority with some amendments and additions. This final paper should be adopted as the "National Boundary Diplomacy/Policy" of the nation, and this particular guideline should be accepted and articulated by the political parties, bureaucracy and technocrats of the states with the counterparts.

7. At last, the Heads of the Governments should have bilateral talks with each other on the basis of national border policy to negotiate and resolve the border demarcation problems. 
8. If the high-level diplomatic negotiations cannot come into concrete conclusion, then diplomatic tactics should be initiated to seek mediation diplomacy from a third state. Both the states should entrust the issue to the mediating state.

9. If mediation diplomacy is unsuccessful or the issue is not entrusted to the third state, then the subsequent step is to seek help from international institutions or organisations, such as the United Nations Security Council or International Court of Justice. Before going to an international organisation with a petition, it is the virtue of a country to inform the neighbouring country officially.

10. Regarding border dispute issues, the states could seek the help of international organisations for the preservation of national sovereignty and upholding its integrity, if the issues cannot be negotiated, mediated and resolved amicably. There should be national consensus regarding boundary issues - no political parties or organisations or individuals shall be entertained by international organisations on the subject of boundaries (Shrestha, Border War, 2013).

Nepal's new foreign policy document- 2077 has demanded to resolve the border disputes with the help of historical records. Nepal's border diplomacy consists of two facets of the same coin. First is border demarcation diplomacy and another is border management diplomacy.

\section{Nepal-India Border Demarcation Diplomacy}

The border demarcation between Nepal and India started after the Treaty of Sugauli-1816, and was later carried out in 1817-1820, 1859-1860, 1880-1883, and 1940-1941 (Baral, 2018). During the British period, Jange Border Pillars were established at every 5-7 miles. There were some blurred boundaries, because of which straight lines were not created between the pillars. To establish subsidiary and minor pillars on the zigzag boundary between two key pillars, a Nepal-India Joint Technical Level Boundary Committee was formed in 1981, which continued its work till 2007. The following is an account of the border demarcation diplomacy between Nepal and India:

1. During 1981-2007, the technical committee demarcated 97 per cent of the borderline, and 182 strip-maps (91 sheets from each side) were prepared. However, the technical committee could not resolve 3 per cent of the borderline due to the border disputes at Kalapani, Susta and some other places (Baral, 2018). The unresolved boundary constitutes nearly 38 kilometres of boundary line out of the 1,880 kilometres of border between Nepal and India.

2. At present, both the states need to prepare around 23 strip maps and have to erect and maintain 4,193 (49 per cent) pillars on the ground. Of the total 
pillars established, nearly 500 (6 per cent) pillars have also been washed away by the rivers and disappeared on the ground (Nayak, 2020).

3. Of the unresolved borders between the two states, there are encroachments, disputes, cross-holding occupations, claims and counter-claims at more than 71 places of around 606 square kilometres in area. The largest encroachment is of Lipulek-Kalapani-Limpiyadhura in Darchula district, which is nearly 335 square kilometers in area. The second disputed/ encroached area is Susta of about 145 square kilometres in Nawalparasi district. Besides, there are disputes, claims, counter-claims and crossholding occupations at 69 other places comprising around 89 square kilometres of land. The smallest piece of encroachment is 240 square metres (nearly half a ropani) of land, located at Phatak of Pashupatinagar Municipality in Ilam district (Shrestha, International Boundaries of Nepal, 2019, p. 163).

Thus, for resolving the disputes between Nepal and India, and for the management of the borders in the future, border management diplomacy should be conducted between the states effectively. The unsettled areas should be handled according to the norms of border demarcation diplomacy. Moreover, a High-Level Border Research Council consisting of former prime ministers (as chief commissioners) along with Track-II diplomats capable of explaining legal treaty, senior cartographers with knowledge in mapping international boundaries, and security professionals with experience in the norms and standards of security perception, should be formed to settle these issues (Shrestha, 2013).

Furthermore, the states must prepare national documents with facts and figures, maps and documents ascribed with previous accidents and incidents on the border issues with India and China. These documents should be discussed at a high-level political leadership, which will aid Nepal in its positive and preventive diplomacy with India. In this, everyone, including political leaders, government officials, intellectuals, activists, and civic society people, must speak.

\section{Issue of Political Map of India: An Explainer}

On November 2, 2019, India published a new "Political Map of India" that included the area of Lipulek-Kalapani-Limpiyadhura (Jain, 2019) within its frontier, encroaching nearly 335 square kilometres of Nepal's territory. In response to this, there were protests and demonstrations all over Nepal against India, and even in some other parts of the world where the Nepali community and non-resident Nepalis resided. In response to the action by India, the Nepali Ministry of Foreign Affairs issued a 
press release on November 6 that said, "The Government of Nepal is clear that Kalapani region is an integral part of Nepal", and that all the disputes between the two states must be settled through bilateral dialogue (Ministry of Foreign Affairs, 2019). What is important is that the earlier edition of the map entitled "At End of British Period 1947", published by the East India Company, has depicted Kalapani region in the territory of Nepal (Bhusal, 2020).
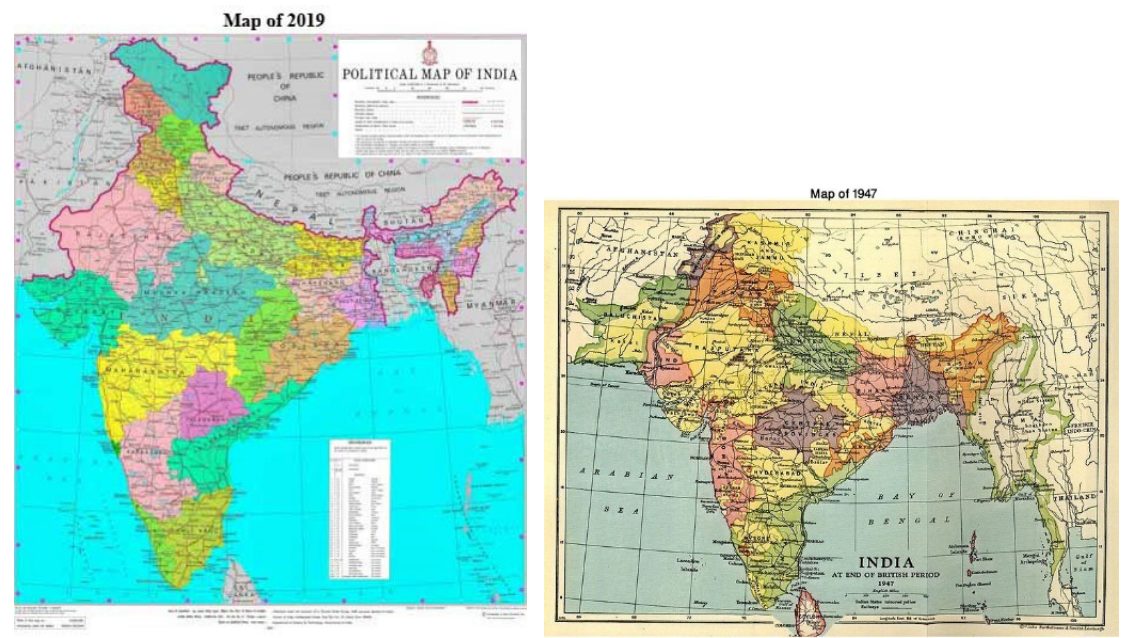

In reply to Nepal's press release, on November 7, 2019, Spokesperson of the Ministry of External Affairs of India Raveesh Kumar stated that India's political map accurately depicts the sovereign territories of India and the new map in no manner has revised India's boundary with Nepal (Ministry of External Affairs, Government of India, 2019). With regard to the issue, Prime Minister of Nepal K P Sharma Oli called a meeting of the leaders of all the parties, foreign policy experts and intellectuals for a meeting on November 9, which unanimously decided that Kalapani belonged to Nepal and a diplomatic solution with India was needed on the Kalapani issue. Later, India published a revised 9th edition of the map on November 18, in which the word "KALI", which was mentioned in the previous edition, was deleted (Survey of India, 2019). 

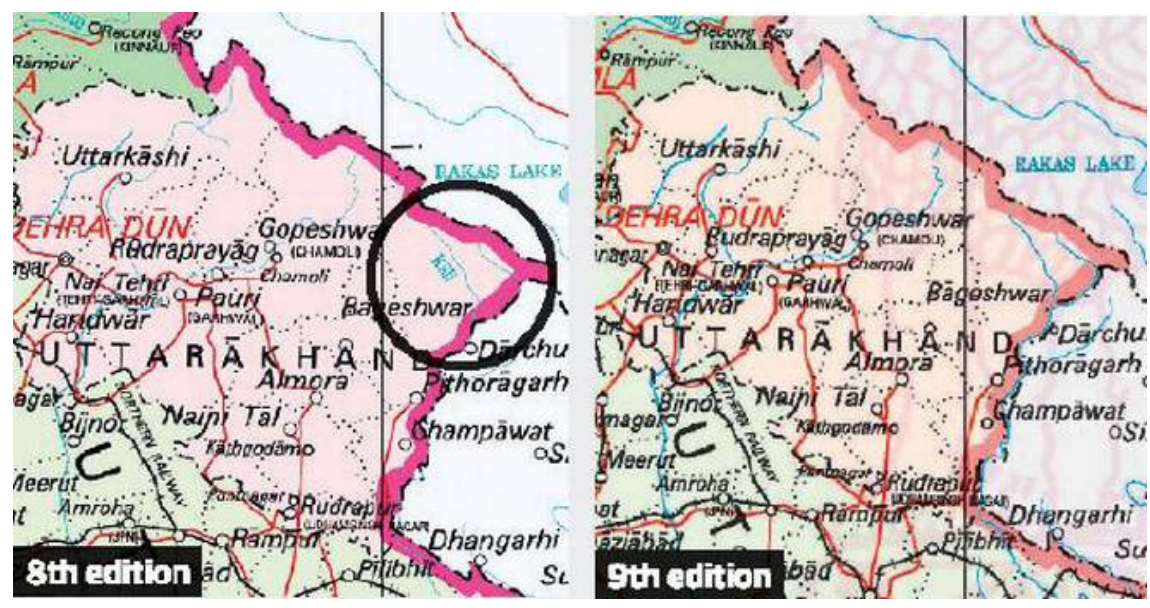

On November 23, 2019, the Ministry of Foreign Affairs, Government of Nepal sent a diplomatic note to India suggesting a Foreign Secretary-level joint dialogue, which was previously formed on August 14, 2014 (Neupane, 2019). On the border dispute in the Lipulek-Limpiyadhura-Kalapani region, Prime Minister Oli was firm about the political map of Nepal, including the region. Deputy Prime Minister and Minister for Defense Ishwar Pokharel made an aerial inspection of the Kalapani region from the Byas area of Nepal on February 17 (The Rising Nepal, 2020). Also, India published two maps on February 28: one in Hindi (Bharatka Rajnneetik Manchitra) and the other in Sanskrit language (Bharatasya Rajnaitik Manachitram) (Survey of India, 2020).

In the House of Representatives of Nepal, a proposal was registered to have Indian troops removed from the Nepal-India border in the Kalapani region and the encroached land returned to Nepal. It was proposed by lawmaker Khagaraj Adhikari and seconded by lawmaker Ram Kumari Jhankri. Later this agenda was removed from the discussion of the meeting of the House of Representatives on March 12, 2020 (Kantipur Daily, 2020). Further, India's cartographic manipulation to include the Lipulek-Limpiyadhura-Kalapani area into its frontier was under shadowed by the issue of the Millennium Challenge Corporation (MCC), the US-proposed assistance for Nepal, around February-March 2020. In between, the coronavirus pandemic was spreading, and the country entered into a strict lockdown from March 24, 2020 for nearly three months. Thus the issue of Indian occupation of the Kalapani area since 1962 lost focus.

The border dispute between Nepal and India heightened after Indian Defence Minister Rajnath Singh virtually inaugurated an 80-kilometre-long link road from Pithoragarh to Lipulek on May 8, 2020 by virtual means in the presence of Indian Army Chief and Chief of Defence Staff despite the threat of the global 
pandemic (Giri, 2020). The link road has been constructed on the sovereign land of Nepal occupied by India. This incident fuelled another cycle of protests in Nepal, resulting in unprecedented unity among the Nepali people.

Concerning the border dispute, President of Nepal Bidhya Devi Bhandari, while presenting the Nepal Government's policies and programmes in the Federal Parliament on May 16, 2020, reiterated that Nepal would issue a new political map incorporating Limpiyadhura. The President emphasised that the land belonged to Nepal and that the disputes should be resolved through diplomatic measures. Accordingly, a meeting of the Council of Ministers was held on May 18, 2020, which decided to publish a new map of Nepal that included Lipulek, Limpiyadhura and Kalapani. Following the decision, the Ministry of Land Management, Cooperatives and Poverty Alleviation officially released a new map entitled "Political and Administrative Map of Nepal" on May 20, 2020 (The Kathmandu Post, 2020).

In response, India's Ministry of External Affairs stated that Nepal's decision was a unilateral act and not based on historical facts and figures and urged the Government of Nepal to respect India's sovereignty and territorial integrity (Ministry of External Affairs, Governmen of India, 2020). Indian Defense Minister Rajnath Singh also indicated that issues including Lipulek should be resolved through dialogue between the two countries (Hindustan Times, 2020). Nonetheless, the Ministry of Law, Justice and Parliamentary Affairs registered a constitution amendment bill at the Parliament to update the map of Nepal in the national emblem as per the new political and administrative map issued by the Government of Nepal. On June 9, 2020, the House of Representative unanimously validated the second amendment to the constitution of Nepal to update the new political and administrative map in the national emblem (Ghimire, 2020).

\section{Nepal-China Border Demarcation Diplomacy}

Nepal's border with the Tibet region of China measures 1,415 kilometres along the Himalayan range. Nepal and China established diplomatic relations in 1955 and exchanged resident ambassadors in 1960. That year, Nepal experienced border conflicts with China at 35 places, including Mount Everest. On October 5 , 1961, to settle its boundary disputes with China, a Nepal-China Joint Boundary Commission was established. Thus, the border between Nepal and China was demarcated jointly during 1961-1962. It was settled cordially with the spirit of friendliness, brotherhood, equality, mutual respect, and on the basis of the principles of Panchasheel. It is admirable that the disputes were resolved at the technical level. 
Nevertheless, the issues over Mount Everest was settled at the prime ministerial level during the visit of Chinese Prime Minister Chou-en-Lai to Nepal on April 28, 1960. The Boundary Protocol was later signed on January 20, 1963 (Shrestha, 2003). It said the border would be regulated and maintained harmoniously by Nepal and China by following the below procedures:

1. Renewal of the Boundary Protocol shall be done every 10 years after joint inspection of the border. A joint report shall be prepared in the course of renewing the previous Protocol after joint supervision and monitoring of the borderlines.

2. Damaged and missing border pillars and markers shall be repaired and established accordingly.

3. By adopting new technology such as Global Positioning System (GPS) observations and establishment of Geographical Information System (GIS) data, new strip maps shall be prepared based on previous maps.

4. With equal cooperation of both India and China, India-Nepal-China Trijunction Points (Zero Marker) needs to be established on both ends of the borderline (Shrestha, Border War, 2013).

5. Nepal and China share a harmonious boundary relation, and to promote this peaceful border sharing, regulated boundary monitoring and supervision are required. To manage the borders, certain managerial tasks should be performed diplomatically by both the states.

\section{Border Management Diplomacy}

Border management is concerned with expediting the movement of people, goods and services legitimately across international borders. It enables legitimate travel and commerce, safeguarding human rights and encouraging human contacts. Moreover, border management includes maintaining safe and secure borders, and meeting national legal requirements. Several government organisations are involved and exercised for effective border management (Shrestha, 2003b, p. 74).

Nepal's border management diplomacy should be implemented on the foundation of dynamic equilibrium with both China and India. Late King Prithvi Narayan Shah characterised Nepal as a "yam between two boulders". But circumstances have changed, and it has to be re-defined in the shifting context of not only Nepal but also owing to the changing situations in China and India. Nepal today aims to act as a bridge between the two Asian giants (Shrestha, 2013). 


\section{Nepal-China Border Management Diplomacy}

Certain Nepali settlements like Chyanga and Lungdep of Kimathanka VDC of Sankhuwasabha district and some forage lands of Humla and Dolakha districts have been demarcated inside China. Also, certain Chinese land has been demarcated as belonging to the Nepali side. Presently, there are two problems between Nepal and China. The first is border marker number 57 of Lapchigaun of Lamabagar area of Dolakha district, and another is the height of Mount Everest (Jha, 2010). Nepal-China border management diplomacy should, thus, include the following concerns for harmonious border relations:

1. Nepal and China have a synchronized border management system. Yet, Tibetans illegally enter Nepal through the borders. So border management should be strengthened from both the sides to regulate illegal migration/ travel.

2. Border outposts and immigration check-posts should be established close to the border crossing points, which will prevent anti-China activity from Nepali soil. At present, these posts are positioned 10-20 kilometres from the borderline. For example, Lamabagar Police Post in Dolakha district has been established 22 kilometres south of the border crossing point. It should be established at Lapche Gaun for proper monitoring.

3. Policy to increase the number of Border Observation Post (BOP) of the Armed Police Force should be adopted to regulate illegal Tibetan infiltration.

4. Nepali timber, Himalayan herbs including the expensive Yarsagumba of Nepal and Red Sandalwood brought from India should be inspected to stop illegal exports to the Tibetan Autonomous Region of China by establishing BOPs close to border crossing-points (Shrestha, 2013).

\section{Nepal-India Border Management Diplomacy}

As Nepal and India have several border disputes, a proper border management system should be adopted through bilateral diplomatic means. Proper border management will not only ensure friendly relations between the states but also aid in the security aspect of both the countries. So, as part of border management diplomacy, the following should be implemented:

1. At the moment, an open border system is practised between Nepal and India. But from a security perspective, this system has not helped both the states. So this open border system should be transformed into a regulated system through mutual co-operation for the security of both the nations. Policies should be taken to regulate the border in a phase-wise manner.

2. To regulate the open border, the number of Armed Police Force and BOPs should be increased in the first phase. The BOP should be established near the borderline, but not on no man's land (Dasgaja Area). Currently, 
several of these posts are located 2-4 kilometres from the border towards the Nepal side.

3. In the second phase, an identity card (ID card) system should be introduced for the travellers and others to cross the Nepal-India border. However, inhabitants living near the borders or within five kilometres of the borders should be permitted to cross the border several times a day.

4. In the third phase, barbed-wire fencing should be erected along the border. There needs to be 376 exit/entry crossing-points since the length of the border is 1,880 kilometres. It's the right time to standardize the NepalIndia border to prevent cross-border terrorism, criminal activities and smuggling of counterfeit Indian currency notes. Such a regulated system could be started with a joint decision as on the air route, following the hijacking of an Indian aircraft from Nepal (Shrestha, 2013).

Nepal through border diplomacy needs to manage its borders with both China and India to effectively regulate the borders to keep tabs on migration, prevent terrorist activities and other transnational organised crimes and resolve the border disputes.

\section{Border Diplomacy to Resolve Border Disputes}

In terms of resolving the border dispute, especially with India, Nepal should be clear about its border diplomacy and boundary strategies to resolve the longstanding issues. In this regard, the following diplomatic approaches and strategies should be adopted:

- Nepal's principal strategy should be to sustain, insist, present and resolve the border disputes with India based on the fundamental principle of sovereign equality, and equal rights and status in the international arena as a sovereign state irrespective of size. Also, diplomatic initiatives should be taken to convince the Indian authorities and build up the confidence for a mutual understanding of the border disputes.

- The dispute should be resolved at the executive high level of the state to enhance the gravity and ensure the implementation of the results after the discussions.

- Nepal should focus on creating a congenial atmosphere and environment for India, a "face-saving strategy" in the international arena to overcome the adverse results after the discussions.

- Lobbying must be made through the Nepali embassies and Nepal's diplomatic missions abroad to garner support with persuasion for solution from the international platforms.

- A mature and experienced diplomatic medium should be the fundamental strategy to convince India to hold bilateral talks and dialogue. 
- Track-II Diplomacy through diplomats and intellectuals should be practised for formal and informal dialogues with the Indian counterparts to resolve the outstanding complex border issues.

- To gather and organise evidences, a high-level border research council should be formed. The council should identify the main cause of the problems through a consultative approach, and also pinpoint the ways and means to solve the problems with alternative measures agreeable to both the states. Further, the council must prepare a "National Document on Boundaries", a repository for future discussions (Shrestha, 2019).

- Thereafter, discussion and dialogue should be held among the political leaders on the documents and reports in a cordial manner given the sensitivity of the issue, as it is related to sovereignty and territorial integrity.

- Through the rigorous interactions among the political leaders, intellectuals, professionals and critics, all must reach a consensus that will ultimately be adopted as the national border diplomacy of Nepal.

- If the problems cannot be solved through mutual interaction and bilateral diplomatic dialogue, there should be briefings on the issue at international forums to build an environment supportive of Nepal. Thus, diplomatic activities should be aligned to create global pressure on India.

- For the settlement of disputes through peaceful means, Nepal should seek third-country mediation. If the mediation is not accepted by the neighbour, Nepal should initiate measures to resolve the issue through international organisations such as the United Nations (Security Council and Geospatial Cartographic Division) and International Court of Justice (ICJ) for safeguarding our sovereignty and territorial integrity (Shrestha, Border War, 2013).

Furthermore, Nepal's border diplomacy should be able to anticipate the possible outcomes of the discussions and draw up strategies required to tackle the probable circumstances in the negotiations.

\section{Possible Outcomes and Border Strategy}

In the bilateral discussions and dialogues, one can conjecture various possibilities and propositions by India. To handle and tackle those situations and circumstances, the concerned stakeholders should plan strategies accordingly to avoid a diplomatic conundrum or stalemate. Thus, Nepal should be prepared for the following possible circumstances and prepare a strategy:

- Nepal should prepare a comprehensive strategy if India claims that Kalapani is an integral part of India;

- A counter-strategy must be prepared in case India comes up with 
documents showing how King Mahendra had handed over Kalapani to the Indian side;

- Adiplomatic strategy should be formed to create an environment conducive for China to ease the situation in favour of Nepal if India claims that China has not agreed that Kalapani belongs to Nepal, as the area forms a trijunction among the three states;

- A policy should be prepared to oppose India should it propose creating the Kalapani region as a buffer zone or no man's land;

- Nepal should be ready with a scheme if the situation leads towards leasing the region of Kalapani for a certain period;

- A strategy should be prepared to opt for a mediating third state if India proposes or accepts third-party mediation;

- An approach should be in place in the event of a confrontation, then Nepal must prepare to take the issue to international forums.

Nepal should focus on diplomatic and peaceful means to resolve the border disputes with India. But it must be able to anticipate the possible outcomes and probable situations that may arise during the negotiations, for which it will have to devise comprehensive strategies to deal with them.

\section{Conclusion}

As diplomacy is an art in international politics involving actors ranging from heads of States to diplomatic envoys, the concept of border diplomacy is particularly related with border demarcation, border management and the settlement of border disputes through diplomatic means and practices including negotiation, enquiry, mediation, conciliation, arbitration, judicial settlement, or resorting to regional agencies or arrangements or other peaceful means could be employed for the settlement of disputes. At present, there are many international boundary disputes, and one of the major ways of settling such issues is through mediation. The U.S. President has been seen eager to mediate such disputes between India and Pakistan and India and China. An integral part of border diplomacy is the demarcation of the boundary and its management. With regard to border demarcation between Nepal and its two neighbours, there are several disputes with India whereas almost all the disputes between Nepal and China have been resolved through diplomatic means. Nepal-India border dispute in the region of Lipulek-Limpiyadhura-Kalapani has hogged the limelight because of cartographic manipulation and construction of a link road through the region by India. 
Thus border management diplomacy should be adopted by both the states to resolve this issue peacefully. Nepal should be prepared for all eventualities with plans, policies and strategies to claim the sovereign land back from Indian occupation diplomatically and peacefully. Moreover, a psychological and suggestive study should be conducted to get a clear public view on the alternatives of the existing border regimes for formulating policies that accommodate the peoples of both the frontiers. As the prime sufferers of any border dispute are the inhabitants close to the borders, the policies regarding integrated development, including physical, social and economic development, should be formulated and implemented. In conclusion, the border disputes should be settled diplomatically through bilateral discussion based on historical maps and documents in the spirit of mutual understanding, friendliness and good neighbourhood. Both the sides should remember that Nepal and India have historical relations with cohesive social, culture and religious connectivity, not only at the political level but also at the diplomatic level.

\section{References}

Anne-Laure, \& Szary, A. (2015). Boundaries and borders. Handbook of Political Geography, Wiley-Blackwell Publication.

Baral, T. N. (2018). Border Disputes and Its Impact on Bilateral Relation: A Case of NepalIndia International Border Management. Journal of APF Command and Staff College, 28-36.

Bhusal, J. K. (2020). Evolution of cartographic aggression by India: A study of Limpiadhura to Lipulek. The Geographical Journal of Nepal, 13, 47-68. doi:http://doi. org/10.3126/gjn.v13i0.28151

Bruns, B. (2017). Homogenous and Extra-territorial Border Regime? Migrations and Control Efforts Across the Eastern EU External Border. Journal of Borderlands Studies.doi:http://www.tandfonline.com/action/showCitFormats ?doi $=10.1080 / 08865655.2017 .1402194$

Chetail, V. (2003). The contribution of the International Court of Justice to international humanitarian law. ICRC.

Constantinou, C. M. (1996). On the Way to Diplomacy. Minnesota, USA: U of Minnesota Press.

Ghimire, B. (2020, June 9). Lower House unanimously endorses proposal to consider amendment to constitution to update new Nepal map in national emblem. Retrieved from The Kathmandu Post: https://kathmandupost.com/ national/2020/06/09/constitution-amendment-bill-is-presented-in-parliamentfor-discussion

Giri, A. (2020, May 8). India Opening a road via Lipulek, a territory that Nepal claims, is a diplomatic failure. Retrieved from The Kathmandu Post: https:// 
kathmandupost.com/national/2020/05/08/india-opening-a-road-via-lipulekha-territory-that-nepal-claims-is-a-diplomatic-failure

Hamza, A. M., \& Todorovic, M. (2017). Peaceful Settlements of Disputes. Global Journal of Commerce and Management Perspective, 11-17.

Heinrich-Böll-Stiftung. (2004). The Role of International Law in a Globalized World. Berlin: Heinrich Böll Foundation.

Henrikson, A. K. (2000). Facing Across Borders: The Diplomacy of Bon Voisinage. International Political Science Review, XXI(2), 121-147.

Hindustan Times. (2020, June 15). 'Bound by roti-beti': Rajnath Singh says IndiaNepal ties are unbreakable, beyond ordinary. Retrieved from Hindustan Times: https://www.hindustantimes.com/india-news/bound-by-roti-betirajnath-singh-says-india-nepal-ties-are-unbreakable-beyond-ordinary/storyYp0U5Hd5vRe9dyC1zNRIbJ.html

International Crisis Group. (2012). Pakistan's Relation with India: Beyond Kashmir. International Crisis Group.

Jain, B. (2019, Novmember 2). Government Releases New Political Map of India Showing UTs, of J\&K, Ladakh. Retrieved from The Times of India: https://timesofindia. indiatimes.com/india/govt-releases-new-political-map-of-india-showing-utsof-jk-ladakh/articleshow/71867468.cms

Jha, H. B. (2010). Nepal's Border Relations with India and China. Eurasia Border Review, 63-75.

Kantipur Daily. (2020, March 13). सीमा संकल्प प्रस्ताव कार्य सूचीबाटै हट्यो. Retrieved from Kantipur Daily: https://epaper.ekantipur.com/kantipur/2020-03-13/

Kazmin, A. (2020, May 27). Donald Trump offers to mediate in India-China border dispute. Retrieved from Financial Times: https://www.ft.com/content/ce361221-6f194e77-b83b-de6fa1bc2fob

Kertesz, S. D., \& Fitzsimons, M. (1959). Diplomacy in A Changing World. Indiana: University of Notre Dame Press.

Kim, S.-h., \& Snyder, S. A. (2019). Denuclearizing North Korea: Time for Plan B. The Washington Quarterly, XLII(4), 75-90. doi:https://www.tandfonline.com/ action/showCitFormats?doi=10.1080/0163660X.2019.1694271

Laskar, R. H., \& Patranobis, S. (2020, May 30). India, China reject US bid to mediate on border issue. Retrieved from The Hindustan Times: https://www. hindustantimes.com/india-news/india-china-reject-us-bid-to-mediate-onborder-issue/story-nZWAd5QJAkzqzpuAjMwsiM.html

Martínez, R. Z. (2018). The Paradiplomacy of Subnational Governments . Universidad Autónoma de Manizales, 17-41.

McMahon, C. S. (1935). International Boundaries. Journal of the Royal Society of Arts, LXXXIV(4330), 4.

Melissen, J. (2005). The New Public Diplomacy: Between Theory and Practice. In J. Melissen (Ed.), The New Public Diplomacy. New York: Palgrave Macmillan.

Ministry of External Affairs, Governmen of India. (2020, May 20). Official Spokesperson's 
response to media queries on the revised map of Nepal released today by Government of Nepal. Retrieved from Ministry of External Affairs, Governmen of India: https://www.mea.gov.in/response-to-queries.htm?dt1/32697/Official_ Spokespersons_response_to_media_queries_on_the_revised_map_of_Nepal_ released_today_by_Government_of_Nepal

Ministry of External Affairs, Government of India. (2019, November 8). Transcript of Weekly Media Briefing by Official Spokesperson (November 7, 2019). Retrieved from Ministry of External Affairs: https://mea.gov.in/mediabriefings.htm?dtl/32019/Transcript + of + Weekly+Media+Briefing + by + Official + Spokesperson+November $+7+2019$

Ministry of Foreign Affairs. (2019, November 6). Press Release. Retrieved from Ministry of Foreign Affairs: https://mofa.gov.np/\%E0\%A4\%AA\% E $0 \%$ A $5 \% 8$ D $\%$ E $0 \%$ A $4 \%$ B $0 \%$ E $0 \%$ A $5 \% 87 \%$ E $0 \%$ A $4 \%$ B 8 - $\%$ E $0 \%$ A $4 \%$ B $5 \%$ E $0 \%$ A $4 \%$ BF $\%$ E $0 \%$ A $4 \% 9$ C $\%$ E $0 \%$ A $5 \% 8$ D $\%$ E $0 \%$ A $4 \%$ 9 E $\%$ E $0 \%$ A $4 \%$ A A $\%$ E $0 \%$ A $5 \% 8$ D $\%$ E $0 \%$ A $4 \%$ A $4 \%$ E $0 \%$ A $4 \%$ B F $\%$ E0\%A4\%A $8 \%$ E0\%A5\%87\%E0\%A4\%AA\%E0\%A4\%BE\%E0\%A4\%B2$\% \mathrm{E} 0 \% \mathrm{~A} 4 \% \mathrm{AD} \% \mathrm{E} 0 \% \mathrm{~A} 4 \% \mathrm{BE} /$

Nayak, S. (2020). India and Nepal's Kalapani Border Dispute: An Explainer. New Delhi: Observer Research Foundation. Retrieved from Observer Research Foundation.

Neupane, S. R. (2019, November 22). Nepal sends a diplomatic note to India over Kalapani issue. Retrieved from The Kathmandu Post: https://kathmandupost.com/ national/2019/11/22/nepal-sends-a-diplomatic-note-to-india-over-kalapaniissue

Nordquist, K.-A. (2010). Boundary Conflicts and Preventive Diplomacy. Sweden.

Read, C. (1990). Border Diplomacy: The Caroline and McLeod Affairs in Anglo-AmericanCanadian Relations, 1837-1842. The Canadian Historical Review, 551-557.

Roche, E. (2020, September 23). Donald Trump again offers to mediate between India and Pakistan on Kashmir. Retrieved from LiveMint: https://www.livemint. com/news/world/donald-trump-again-offers-to-mediate-between-india-andpakistan-on-kashmir-1569261681065.html

Sargsyan, I. (2003). International Mediation in Theory and Practice. ACNIS Academic Council.

Shrestha, B. N. (2003a). Border Issues of Nepal: With Special Reference to India. Hydroresources Development, Water Sharing, Border Issues and Treaty of Different Countries. Hyderbad, India.

Shrestha, B. N. (2003b). Border Management of Nepal. Kathmandu: Bhumichitra Co. Pvt. Ltd.

Shrestha, B. N. (2013). Border War. Kathmandu: Ratna Sagar Publications Pvt. Ltd.

Shrestha, B. N. (2014, June 14). Nepal-India border needs to be regulated. (R. Nepal, Interviewer)

Shrestha, B. N. (2019). International Boundaries of Nepal. Latvia: Lambert Academic Publishing. 
Sigal, L. V. (2020). Paved with Good Intentions: Trump's Nuclear Diplomacy with North Korea. Journal for Peace and Nuclear Disarmament, 163182.doi:https://www.tandfonline.com/action/showCitFormats?d oi $=10.1080 / 25751654.2020 .1751549$

Srebro, H., \& Shoshany, M. (2013). International Boundary Making. Paris: International Federation of Surveyors.

Survey of India. (2019, November 8). Govt. of India released new political map of India 9th edition ,2019. The map prepared by Survey of India(DST) Govt. of India. Retrieved from Survey of India: http://www.surveyofindia.gov.in/news/ view/147

Survey of India. (2020, February 28). Political Map Of India. Retrieved from Survey of India: http://www.surveyofindia.gov.in/pages/display/235-political-map-ofindia

The Kathmandu Post. (2020, May 20). Government Unveils New Political Map Inclusing Kalapani, Lipulek and Limpiyadhura Inside Nepal Borders. Retrieved from The Kathmandu Post: https://kathmandupost.com/national/2020/05/20/ government-unveils-new-political-map-including-kalapani-lipulekh-andlimpiyadhura-inside-nepal-borders

The Rising Nepal. (2020, February 17). DPM Pokhrel Makes Aerial Inspection Of Kalapani. Retrieved from The Rising Nepal: https://risingnepaldaily.com/main-news/ dpm-pokhrel-makes-aerial-inspection-of-kalapani

The United Nations. (2017). Un Charter- Chapter VII. Retrieved from The United Nations: https://www.un.org/en/sections/un-charter/chapter-vii/index.html

The United Nations. (2017). UN Charter-Chapter VI. Retrieved from The United Nations: https://www.un.org/en/sections/un-charter/chapter-vi/index.html

Ullah, A. K., \& Kumpoh, A. A.-Z. (2018). Are Borders the Reflection of International Relations? Southeast Asian Borders in Perspective. Journal of Asian Security International Affairs, V(3), 1-23. doi:10.1177/2347797018798253

Ullah, A. K., \& Kumpoh, A. A.-Z. (2018). Are Borders the Reflection of International Relations? Southeast Asian Borders in Perspective. Journal of Asian Security and International Affairs, V(3), 295-318.

US Embassy and Consulate in the Republic of Korea. (2019, June 30). U.S. President Donald Trump (left) meets with North Korean Chairman Kim Jong Un (center) and South Korean President Moon Jae-in. Retrieved from US Embassy and Consulate in the Republic of Korea: https://kr.usembassy.gov/063019-photou-s-president-donald-trump-meets-north-korean-chairman-kim-jong-un-atdmz/0630p2/ 